\title{
Immunological modulation of mesenchymal stem cells in repairing of acute kidney injury
}

\author{
Qin Tan and Yichuan $\mathrm{Li}^{*}$ \\ Department of Anesthesiology, Shanghai Jiaotong University Affiliated Sixth People's Hospital, Shanghai, China.
}

\begin{abstract}
Mesenchymal stem cells (MSCs), as a potential therapeutic, have been put into a great quantity of preclinical or clinical researches which are considered as one of the pivotal parts in the tissue repairation. A body of evidence have demonstrated that, acute kidney injury(AKI) which is described as a complex pathophysiology containing a series of innate and adaptive immune responses, has a satisfactory morphological and functional recovery owing to the MSCs potentially because the multiple functions like adhesion, proliferation or differentiation, restoration and immunosuppressive effect. The present review will focus on the exploration of MSCs in AKI detailed in immunologic system as far as possible.
\end{abstract}

\section{Introduction}

The patients suffering from Acute kidney injury (AKI), in spite of the development of the medicine, have an increase in number during these years, especially in the Intensive Care Unit (ICU). Although early diagnose and seasonable supportive treatment were given to the patients, the results always came to a long-term risk of chronic disease, end-stage renal disease, or even the death [1]. It has been reported that AKI occurs in approximately 13 million people in the whole world every year and leads to 13 percent of the death rate [2]. Kidney units which make great demands on ATP supply and flood flow due to their filtration and reabsorptive process are vulnerable to ischemia, nephrotoxin or sepsis $[1,3]$. Even though the mechanisms involving in $\mathrm{AKI}$ is much more complex, innate and adaptive immune responses play a key role in the pathophysiology [4,5].

Mesenchymal stem cells (MSCs) which can be obtained from multiple resources, like bone marrow, skeletal muscles, umbilical cord vein, peripheral blood and adipose tissue, are the most critical part consisting of tissue remodeling and post-damage reparation [6]. A succession of studies have demonstrated that MSCs can be useful in the treatment in the different types of experimental AKI models [7]. The properties of MSCs are their capability of secreting molecules and their potential for differentiation and proliferation in the other tissues [8]. Otherwise, these cells have shown their immunosuppressive capability likely related to the lack or low expression of class II major histocompatibility complex (MHC-II) and co-stimulatory molecules on cell surface, which can affect different pathways of the immune responses [9]. Moreover, the process of MSCs preferentially migrating into damaged tissues, which is called homing $[10,11]$, have grasped the notion of researchers recently and high-quality studies have found that injured renal endothelial and tubular epithelial cells can interact with MSCs by signaling molecules, such as chemokines, adhesion molecules and matrix metalloproteinases [11-13]. Nonetheless, the specific mechanisms of the immune modulations of MSCs are still unknown. This review is bound to summarize recent studies on the application of MSCs in AKI emphasizing on their immune-privileged effect.

\section{Innate immune responses}

\section{Neutrophils and nature killer cells}

As well as an important inflammatory cell, neutrophil plays a key role in the initial process of AKI where neutrophils roll on endothelium by both ICAM-1 allowing their attachment before their potential transport and TNF inducing their infiltration [14,15]. In addition, rising attention on urinary neutrophil gelatinase-associated lipocalin (uNGAL), a protein expressed by neutrophils [16], which has been studied in recent years, as an indicator of AKI resulting from different clinical incidents [17-20]. Since certain conclusion of uNGAL remains rewarding, the significance of neutrophils in the pathological process of kidney injury cannot be ignored.

NK cells along with neutrophils are the earliest responder to AKI which have been reported to trafficked into the post-ischemic kidney by 4 hours of reperfusion [21]. Unlike T and B lymphocytes, NK cells can lyse target cells instantly without antigen presentation. While NK cells can be stimulated by class I MHC or class I MHC-like ligands on target cells [22] to release cytotoxicity, chemokine and pro inflammatory factors produced by $\mathrm{NK}$ cells also participate in the injury [23,24].

Previous studies have demonstrated that MSCs can reduce the expression of pro-inflammatory cytokines while upregulate the expression of anti-inflammatory cytokines inducing by their paracrine function [25-27]. However, little information is available regarding the mechanism of cellular interactions between MSCs and neutrophils, and the effect of MSCs on NK-mediated cytotoxicity is still uncertain. Some

${ }^{\star}$ Correspondence to: Yichuan Li, Department of Anesthesiology, Shanghai Jiaotong University Affiliated Sixth People's Hospital, Shanghai, China, E-mail: yingchuan.li@sjtu.edu.cn

Key words: mesenchymal stem cells (MSCs), acute kidney injury (AKI), immune modulation

Received: May 06, 2019; Accepted: May 24, 2019; Published: May 28, 2019 
studies have focused on these confusions that in the presence of MSCs, NK cells can be activated with reduction of cytotoxicity releasing and inhibition of proliferation but at the same time MSCs become the target cells because of high expression of HLA-I molecules on their surfaces [27-29].

\section{Macrophages}

The innate immune response to injured kidney involves the recruitment of naive monocytes which is conducted by CCR2 and CX3CR1 signaling pathways [30,31]. The local environment full of termed pathogen-associated molecular patterns(PAMPs) or dangerassociated molecular patterns(DAMPs) along with IFN- $\gamma$ by Th1 T cells and NK T cells, leads to the maturation of macrophages, more accurately, the polarized activation of M1 macrophages, a classical category which is considered as a host defense that induces tissue damage, aggravate inflammation and clear apoptotic cells $[32,33]$. In the contrary, the alternative category of M2 macrophages stimulated by IL-4/IL-13 has a complex function containing wound healing, fibrosis, insulin sensitivity, and immunosuppression [33,34].

Studies have realized the immunomodulation MSCs have on the macrophages [35]. It has been reported that MSCs can induce M2 macrophages in some inflammation-related organ injury which includes our focused point, kidney. Since MSCs have the ability to home and migrate to injured kidney [10], they could not be found in the kidney from the observation of the last experiment [36]. It showed some important data which demonstrated that MSCs could improve kidney injury induced by glycerin inserted along with the increase frequency of M2 macrophages filtration. The protection may result from the increasing number of M2-polarised macrophages by MSCs secreting many soluble factors which make the microenvironment more suitable for M2 phenotype instead of cell to cell interaction. This mechanism also be proved by another study on the AKI induced by ischemia reperfusion [37]. However, it observed the image that MSCs locating in both the lung and kidney tissue. Moreover, MSCs displayed strong their power of proliferation on the tubular epithelial cells. If different origins of MSCs make the variances still needs for further study.

\section{NK T cells}

NK T cells are a unique subset included in T lymphocyte which express a characteristic marker $\mathrm{T}$ cell receptor but simultaneously share some surface antigens like CD161 with NK cells [38]. However, with the further study on NK T cells, it is far from accurate to classify NK $\mathrm{T}$ cells as $\mathrm{T}$ cells that also express NK receptors. The newest definition is CD1d-dependent nature killer-like T cells, in which CD1d is expressed on various cells like dendritic cells and macrophages [39]. Moreover, compared with cytotoxic effect, NK T cells have a more remarkable property that is their ability to rapidly produce large quantities of cytokines such as IFN- $\gamma$, TNF- $\alpha$, IL-4, IL-13 which can induce Th1 or Th2-like effect within 3 hours in the kidney injury [40]. This ability makes NK T cells contact innate immunity with adaptive immunity [41] and plays an important role in pro-inflammatory or anti-inflammatory functions [42]. There are two main types of NK T cells: type I, invariant NK T cells (iNKT cells) that express conservative TCRs and can be stimulated by glycolipid antigens and type II NK T cells that express much more TCRs and can be stimulated by the lipid antigens [39]. Blocking the activation of iNKT cells with the anti-CD1d $\mathrm{mAb}$ or using iNKT cells deficient mice has been demonstrated renal protection in vivo [40]. Another study found that the activation of type II NKT cells could alleviate inflammation and epithelium injury by enhancing the HIF-1 $\alpha$ and IL-10 pathways [43].
Even though few studies can be found surrounding the effect of MSCs on the phenotype or function of NK T cells, some latest reports may inspire new ideas. Experiments on the liver injury induced by a-galactoceramide showed that MSCs had remarkable effect on the decrease of hepatotoxicity of NKT cells $[44,45]$. As the bridge of innate immune and adaptive immune system, also as the primal process of inflammation, NKT cells desire to be more detected.

\section{Adaptive immune response}

\section{T cells}

$\mathrm{T}$ lymphocyte cells are a big family containing various lineages which can be divided in different groups according to different standards. All the T cells express either CD4 or CD8, and naive CD4+ $\mathrm{T}$ cells can further differentiate into Th1 cells, Th2 cells, Th17 cells or other Th cells, which is determined by the surrounding context [46]. Another splenic CD4+ T cells turn into Regulator T cells (Tregs) that suppress the activation of most pro-inflammatory cells [47]. CD8+ T cells become cytotoxic cells that are able to be activated by antigens presented on dendritic cells, tumor cells or infected cells and kill target cells with perforin, granzymes and Fas ligand [48]. NK T cells make up a quite small but significant subgroup of $\mathrm{T}$ cells as mentioned above.

Obviously, CD8+ T cells participate in the pathophysiological process of AKI after receiving the presentation of the antigens which has been well demonstrated in many studies [49-51]. Moreover, the accumulation of activated and effector-memory $\mathrm{T}$ cells can be found in the kidney at 2 and 6 weeks after moderate or severe ischemiareperfusion which is related to the long-term injury and fibrosis whereas the depletion of $\mathrm{T}$ lymphocytes has no protective effect on neither cortex or medulla which needs further experiments to illuminate the mechanism [52].

Regulator T cells (Tregs) are an important subset of T lymphocytes with the identification of a pivotal transcription factor, forkhead box P3(FOXP3), and two kinds of surface marker, CD4 and CD25 [47]. It has been demonstrated that Tregs have particular suppression in effector T cells and other immune responses or even inflammation both in vitro or in vivo probably via cAMP driven cell-contact mechanism $[47,53]$. It is almost certainly that so much attention has been paid on the Tregs to study their potential on the therapeutical application in the AKI.

MSCs have their no immunological restrictions with the low expression of MHC-II and have an effect on almost all $\mathrm{T}$ cell subpopulation, like CD4+ and CD8+ T cells, naive $\mathrm{T}$ cells and memory $\mathrm{T}$ cells $[9,54,55]$. Co-culturing with MSCs may result in a shift of Th function activity from the population with phenotype Th1 which produces pro-inflammatory cytokines IL- 2 and IFN- $\gamma$ that plays a significant role in AKI models, to the Th2 population which produces anti-inflammatory cytokines IL-4 and IL-10 [56,57]. Moreover, MSCs can induce naive $\mathrm{T}$ cells into Tregs due to the suppression of allogeneic lymphocyte proliferation [10,58,59]. Although quite helpful effect has been found in animal models of AKI with the presence of MSCs interaction with Tregs, the unknown mechanism limits its wider application. Jie Hu et al. [11] has promoted that MSCs induce Tregs infiltrating into the injury kidney via an MSC-splenocyte interaction and MSCs have a negative engraftment into the kidney. However, it is contradictory to the homing phenomenon which is characterized that MSCs preferentially migrate to injured tissue responsible for the signaling molecules released from the damaged tissue, like chemokines, adhesion molecules and matrix metalloproteinases and receptors on 
the MSC surface $[11,12]$. Therefore, more studies are required to detect the real world of MSCs.

\section{B cells}

B cells are mediators of various autoimmune diseases, such as experimental allergic encephalomyelitis (EAE), collagen-induced arthritis and inflammatory bowel disease because of their prominent inflammatory response which is similar to the pathophysiology of AKI [60-62]. What's more, B cells contribute to the rejection in renal allograft by differentiating into plasma cells filled up with the kidney [63,64]. Hye Ryoun Jang et al. [65] reported that the traffic of B cells had a negative effect on the repairation of tubular regeneration and the modulation of B cells or targeting CD126 expressed on the surface of mature B cells might have properties on the kidney restoration. Similar to T cells, MSCs can also inhibit B cells in all of their grow-up process, activation, proliferation, differentiation and immunoglobulin production $[66,67]$. However, not enough researches have been focused on the MSCs interaction with B cells in the AKI which gives a novel insight to the following studies.

\section{Summary}

Since it has been known that there is something closely related between immune system and the pathological process of AKI, how do different kinds of immune cells accurately work remains mysterious. Moreover, compared with the damage effect of some immunoreaction, the others which show striking renal protection in the AKI should be paid more attention. Although quite a few kinds of leukocytes like M2 macrophages and B lymphocytes may have beneficial influence on the recovery of kidney, the spectacular positive modulation makes regulatory T cells stand out of these cells. So, why do we not go further?

\section{References}

1. Lameire NH, Bagga A, Cruz D, De Maeseneer J, Endre Z, et al. (2013) Acute kidney injury: an increasing global concern. Lancet 382: 170-179. [Crossref]

2. Mehta RL, Cerdá J, Burdmann EA, Tonelli M, García-García G, et al. (2015) International Society of Nephrology's 0by 25 initiative for acute kidney injury (zero preventable deaths by 2025): a human rights case for nephrology. Lancet 385: 2616-43. [Crossref]

3. Hoenig MP, Zeidel ML (2014) Homeostasis, the milieu interieur, and the wisdom of the nephron. Clin J Am Soc Nephrol 9: 1272-1281. [Crossref]

4. Rabb H (2002) The $\mathrm{T}$ cell as a bridge between innate and adaptive immune systems: implications for the kidney. Kidney Int 61: 1935-1946. [Crossref]

5. Li L, Okusa MD (2006) Blocking the immune response in ischemic acute kidney injury: the role of adenosine 2A agonists. Nat Clin Pract Nephrol 2: 432-444. [Crossref]

6. Crisan M, Yap S, Casteilla L, Chen CW, Corselli M, et al. (2008) A perivascular origin for mesenchymal stem cells in multiple human organs. Cell Stem Cell 3: 301-313. [Crossref]

7. Humphreys BD, Bonventre JV (2008) Mesenchymal stem cells in acute kidney injury. Аnnu Rev Med 59: 311-325. [Crossref]

8. Buravkova LB, Andreeva ER (2010) [Interaction of human multipotential mesenchymal stromal and immune cells]. Fiziol Cheloveka 36: 110-20. [Crossref]

9. English K, Mahon BP (2011) Allogeneic mesenchymal stem cells: agents of immune modulation. J Cell Biochem 112: 1963-1968. [Crossref]

10. Chapel A, Bertho JM, Bensidhoum M, Fouillard L, Young RG, et al. (2003) Mesenchymal stem cells home to injured tissues when co-infused with hematopoietic cells to treat a radiation-induced multi-organ failure syndrome. J Gene Med 5: 10281038. [Crossref]

11. Mahmood A, Lu D, Lu M, Chopp M (2003) Treatment of traumatic brain injury in adult rats with intravenous administration of human bone marrow stromal cells. Neurosurgery 53: 697-702; discussion 702-703. [Crossref]
12. Herrera MB, Bussolati B, Bruno S, Morando L, Mauriello-Romanazzi G, et al. (2007) Exogenous mesenchymal stem cells localize to the kidney by means of CD44 following acute tubular injury. Kidney Int 72: 430-441. [Crossref]

13. Liu N, Tian J, Cheng J, Zhang J (2013) Migration of CXCR4 gene-modified bone marrow-derived mesenchymal stem cells to the acute injured kidney. J Cell Biochem 114: 2677-2689. [Crossref]

14. Wu X1, Guo R, Wang Y, Cunningham PN (2007) The role of ICAM-1 in endotoxininduced acute renal failure. Am J Physiol Renal Physiol 293: F1262-1271. [Crossref]

15. Wu X, Guo R, Chen P, Wang Q, Cunningham PN (2009) TNF induces caspasedependent inflammation in renal endothelial cells through a Rho- and myosin light chain kinase-dependent mechanism. Am J Physiol Renal Physiol 297: F316-26. [Crossref]

16. Mishra J, Ma Q, Prada A, Mitsnefes M, Zahedi K, et al. (2003) Identification of neutrophil gelatinase-associated lipocalin as a novel early urinary biomarker for ischemic renal injury. J Am Soc Nephrol 14: 2534-2543. [Crossref]

17. Almalky MA, Hasan SA, Hassan TH, Shahbah DA, Arafa MA, et al. (2015) Detection of early renal injury in children with solid tumors undergoing chemotherapy by urinary neutrophil gelatinase-associated lipocalin. Mol Clin Oncol 3: 1341-1346. [Crossref]

18. Kesik V, Demirkaya E, Buyukpamukçu M (2015) Urinary neutrophil gelatinase associated lipocalin as a biomarker in ifosfamide induced chronic renal failure. Eur Rev Med Pharmacol Sci 19: 4851-7. [Crossref]

19. Dede O, Dağguli M, Utanğaç M, Yuksel H, Bodakcı MN, et al. (2015) Urinary expression of acute kidney injury biomarkers in patients after RIRS: it is a prospective, controlled study. Int J Clin Exp Med 8: 8147-8152. [Crossref]

20. Ho J, Tangri N, Komenda P, Kaushal A, Sood M, et al. (2015) Urinary, Plasma, and Serum Biomarkers' Utility for Predicting Acute Kidney Injury Associated with Cardiac Surgery in Adults: A Meta-analysis. Am J Kidney Dis 66: 993-1005. [Crossref]

21. Zhang ZX, Wang S, Huang X, Min WP, Sun H, et al. (2008) NK cells induce apoptosis in tubular epithelial cells and contribute to renal ischemia-reperfusion injury. J Immunol 181: 7489-7498. [Crossref]

22. Höglund P, Sundbäck J, Olsson-Alheim MY, Johansson M, Salcedo M, et al. (1997) Host MHC class I gene control of NK-cell specificity in the mouse. Immunol Rev 155: 11-28. [Crossref]

23. Lodoen MB, Lanier LL (2006) Natural killer cells as an initial defense against pathogens. Curr Opin Immunol 18: 391-398. [Crossref]

24. Vujanovic NL (2001) Role of TNF family ligands in antitumor activity of natural killer cells. Int Rev Immunol 20: 415-437. [Crossref]

25. Tögel F, Hu Z, Weiss K, Isaac J, Lange C, et al. (2005) Administered mesenchymal stem cells protect against ischemic acute renal failure through differentiation-independent mechanisms. Am J Physiol Renal Physiol 289: F31-42. [Crossref]

26. Semedo P, Palasio CG, Oliveira CD, Feitoza CQ, Gonçalves GM, et al. (2009) Early modulation of inflammation by mesenchymal stem cell after acute kidney injury. Int Immunopharmacol 9: 677-682. [Crossref]

27. Ionescu L, Byrne RN, van Haaften T, Vadivel A, Alphonse RS, et al. (2012) Stem cell conditioned medium improves acute lung injury in mice: in vivo evidence for stem cell paracrine action. Am J Physiol Lung Cell Mol Physiol 303: L967-L977. [Crossref]

28. Sotiropoulou PA, Perez SA, Gritzapis AD, Baxevanis CN, Papamichail M (2006) Interactions between human mesenchymal stem cells and natural killer cells. Stem Cells 24: 74-85. [Crossref]

29. Spaggiari GM, Capobianco A, Becchetti S, Mingari MC, Moretta L (2006) Mesenchymal stem cell-natural killer cell interactions: evidence that activated NK cells are capable of killing MSCs, whereas MSCs can inhibit IL-2-induced NK-cell proliferation. Blood 107: 1484-90. [Crossref]

30. Oh DJ, Dursun B, He Z, Lu L, Hoke TS, et al. (2008) Fractalkine receptor (CX3CR1) inhibition is protective against ischemic acute renal failure in mice. Am J Physiol Renal Physiol 294: F264-F271. [Crossref]

31. Li L, Huang L, Sung SS, Vergis AL, Rosin DL, et al. (2008) The chemokine receptors CCR2 and CX3CR1 mediate monocyte/macrophage trafficking in kidney ischemiareperfusion injury. Kidney Int 74: 1526-1537. [Crossref]

32. Li L, Okusa MD (2010) Macrophages, dendritic cells, and kidney ischemia-reperfusion injury. Semin Nephrol 30: 268-77. [Crossref]

33. Sica A, Mantovani A (2012) Macrophage plasticity and polarization: in vivo veritas. $J$ Clin Invest 122: 787-795. [Crossref] 
34. Wynn TA, Chawla A, Pollard JW (2013) Macrophage biology in development, homeostasis and disease. Nature 496: 445-455. [Crossref]

35. Kim J, Hematti P (2009) Mesenchymal stem cell-educated macrophages: a novel type of alternatively activated macrophages. Exp Hematol 37: 1445-1453. [Crossref]

36. Geng Y, Zhang L, Fu B, Zhang J, Hong Q, et al. (2014) Mesenchymal stem cells ameliorate rhabdomyolysis-induced acute kidney injury via the activation of M2 macrophages. Stem Cell Res Ther 5: 80. [Crossref]

37. Li W, Zhang Q, Wang M, Wu H, Mao F, et al. (2013) Macrophages are involved in the protective role of human umbilical cord-derived stromal cells in renal ischemiareperfusion injury. Stem Cell Res 10: 405-416. [Crossref]

38. Makino Y, Kanno R, Ito T, Higashino K, Taniguchi M (1995) Predominant expression of invariant $\mathrm{V}$ alpha 14+ TCR alpha chain in NK1.1+ T cell populations. Int Immunol 7: 1157-1161. [Crossref]

39. Godfrey DI, MacDonald HR, Kronenberg M, Smyth MJ, Van Kaer L (2004) NKT cells: what's in a name? Nat Rev Immunol 4: 231-237. [Crossref]

40. Li L, Huang L, Sung SS, Lobo PI, Brown MG, et al. (2007) NKT cell activation mediates neutrophil IFN-gamma production and renal ischemia-reperfusion injury. $J$ Immunol 178: 5899-5911. [Crossref]

41. Arrenberg P, Halder R, Kumar V (2009) Cross-regulation between distinct natural killer $\mathrm{T}$ cell subsets influences immune response to self and foreign antigens. $J$ Cell Physiol 218: 246-250. [Crossref]

42. Godfrey DI, Stankovic S, Baxter AG (2010) Raising the NKT cell family. Nat Immunol 11: 197-206. [Crossref]

43. Yang SH, Lee JP, Jang HR, Cha RH, Han SS, et al. (2011) Sulfatide-reactive natural killer T cells abrogate ischemia-reperfusion injury. J Am Soc Nephrol 22: 1305-1314. [Crossref]

44. Milosavljevic N, Gazdic M, Simovic Markovic B, Arsenijevic A, Nurkovic J, et al. (2018) Mesenchymal stem cells attenuate liver fibrosis by suppressing Th17 cells - an experimental study. Transpl Int 31: 102-115. [Crossref]

45. Gazdic M, Simovic Markovic B, Vucicevic L, Nikolic T, Djonov V, et al. (2018) Mesenchymal stem cells protect from acute liver injury by attenuating hepatotoxicity of liver natural killer $\mathrm{T}$ cells in an inducible nitric oxide synthase- and indoleamine 2,3-dioxygenase-dependent manner. J Tissue Eng Regen Med 12: e1173-e1185. [Crossref]

46. Zhu J, Paul WE (2010) Heterogeneity and plasticity of T helper cells. Cell Res 20: 4-12. [Crossref]

47. Vignali DA, Collison LW, Workman CJ (2008) How regulatory T cells work. Nat Rev Immunol 8: 523-532. [Crossref]

48. Ko GJ, Jang HR, Huang Y, Womer KL, Liu M, et al. (2011) Blocking Fas ligand on leukocytes attenuates kidney ischemia-reperfusion injury. J Am Soc Nephrol 22: 732 742. [Crossref]

49. Ascon DB, Lopez-Briones S, Liu M, Ascon M, Savransky V, et al. (2006) Phenotypic and functional characterization of kidney-infiltrating lymphocytes in renal ischemia reperfusion injury. J Immunol 177: 3380-3387. [Crossref]

50. Burne-Taney MJ, Yokota N, Rabb H (2005) Persistent renal and extrarenal immune changes after severe ischemic injury. Kidney Int 67: 1002-1009. [Crossref]
51. Ibrahim S, Jacobs F, Zukin Y, Enriquez D, Holt D, et al. (1996) Immunohistochemical manifestations of unilateral kidney ischemia. Clin Transplant 10: 646-652. [Crossref]

52. Ascon M, Ascon DB, Liu M, Cheadle C, Sarkar C, et al. (2009) Renal ischemiareperfusion leads to long term infiltration of activated and effector-memory $\mathrm{T}$ lymphocytes. Kidney Int 75: 526-535. [Crossref]

53. Bodor J, Bopp T, Vaeth M, Klein M, Serfling E, et al. (2012) Cyclic AMP underpins suppression by regulatory T cells. Eur J Immunol 42: 1375-1384. [Crossref]

54. Krampera M, Cosmi L, Angeli R, Pasini A, Liotta F, Andreini A, et al. (2006) Role for interferon-gamma in the immunomodulatory activity of human bone marrow mesenchymal stem cells. Stem Cells 24: 386-398. [Crossref]

55. Le Blanc K, Rasmusson I, Götherström C, Seidel C, Sundberg B, et al. (2004) Mesenchymal stem cells inhibit the expression of CD25 (interleukin-2 receptor) and CD38 on phytohaemagglutinin-activated lymphocytes. Scand J Immunol 60: 307-315. [Crossref]

56. Zhang X, Ren X, Li G, Jiao C, Zhang L, Zhao S, et al. (2011) Mesenchymal stem cells ameliorate experimental autoimmune uveoretinitis by comprehensive modulation of systemic autoimmunity. Invest Ophthalmol Vis Sci 52: 3143-3152. [Crossref]

57. Zappia E, Casazza S, Pedemonte E, Benvenuto F, Bonanni I, et al. (2005) Mesenchymal stem cells ameliorate experimental autoimmune encephalomyelitis inducing T-cell anergy. Blood 106: 1755-1761. [Crossref]

58. YeZ, Wang Y, Xie HY, Zheng SS (2008) Immunosuppressive effects of rat mesenchyma stem cells: involvement of CD4+CD25+ regulatory T cells. Hepatobiliary Pancreat Dis Int 7: 608-614. [Crossref]

59. Prevosto C, Zancolli M, Canevali P, Zocchi MR, Poggi A (2007) Generation of CD4 or CD8+ regulatory $\mathrm{T}$ cells upon mesenchymal stem cell-lymphocyte interaction. Haematologica 92: 881-888. [Crossref]

60. Fillatreau S, Sweenie CH, McGeachy MJ, Gray D, Anderton SM (2002) B cells regulate autoimmunity by provision of IL-10. Nat Immunol 3: 944-950. [Crossref]

61. Mauri C, Gray D, Mushtaq N, Londei M (2003) Prevention of arthritis by interleukin 10-producing B cells. J Exp Med 197: 489-501. [Crossref]

62. Mizoguchi A, Mizoguchi E, Takedatsu H, Blumberg RS, Bhan AK (2002) Chronic intestinal inflammatory condition generates IL-10-producing regulatory B cell subset characterized by CD1d upregulation. Immunity 16: 219-230. [Crossref]

63. Sarwal M, Chua MS, Kambham N, Hsieh SC, Satterwhite T, et al. (2003) Molecular heterogeneity in acute renal allograft rejection identified by DNA microarray profiling. N Engl J Med 349: 125-138. [Crossref]

64. Martins HL, Silva C, Martini D, Noronha IL (2007) Detection of B lymphocytes (CD20+) in renal allograft biopsy specimens. Transplant Proc 39: 432-434. [Crossref]

65. Jang HR, Gandolfo MT, Ko GJ, Satpute SR, Racusen L, et al. (2010) B cells limit repair after ischemic acute kidney injury. J Am Soc Nephrol 21: 654-665. [Crossref]

66. Augello A, Tasso R, Negrini SM, Amateis A, Indiveri F, et al. (2005) Bone marrow mesenchymal progenitor cells inhibit lymphocyte proliferation by activation of the programmed death 1 pathway. Eur J Immunol 35: 1482-1490. [Crossref]

67. Corcione A, Benvenuto F, Ferretti E, Giunti D, Cappiello V, et al. (2006) Human mesenchymal stem cells modulate B-cell functions. Blood 107: 367-372. [Crossref]

Copyright: (C2019 Tan Q. This is an open-access article distributed under the terms of the Creative Commons Attribution License, which permits unrestricted use, distribution, and reproduction in any medium, provided the original author and source are credited. 